\title{
Concept and Position of Peremptory Norms (Jus Cogens) in International Law: A Preliminary Study
}

\author{
Irawati Handayani \\ Faculty of Law, Padjadjaran University, Indonesia. \\ E-mail:irawati@unpad.ac.id
}

\section{ARTICLE INFO}

\section{Keywords:}

Jus Cogens; Peremptory

Norms; Sources of

International Law; Public

Order

How to cite:

Handayani, I. (2019).

"Concept and Position of

Peremptory Norms (Jus

Cogens) in International

Law: A Preliminary Study,"

Hasanuddin Law Review,

5(2): 235-252

DOI:

10.20956/halrev.v5i2.1709

\begin{abstract}
Peremptory norms or jus cogens hold a unique position in international law. Unlike customary international law and treaty law, they abide no derivation and bind all states regardless of their willingness to be bound. Some scholars had elaborated fundamental theories to answer the theoretical background of jus cogens. However, they have never reached a satisfactory result. This study aims to elaborate the theoretical background of jus cogens and to observe the relationship between jus cogens, obligation erga omnes, and customary international law. The positivists recognize that jus cogens is an imperative norm within state practice and opinio juris. The positivist theory is not in line with the concept that jus cogens bound to states without their consent since every state has their sovereignty and cannot be bound by any kind of provision without consent. The proponents of the natural law theory stated that peremptory norms are inherited from the tradition of natural law so that it is the highest norm in international law that directly binds countries. On the other hand, the public order theory states that international law recognizes important (imperative) norms, which are hierarchically higher than ordinary norms and customary international law to advance the interests of the international community and to preserve the main values of international law. The three theories are considered insufficient to answer the philosophical basis of jus cogens. In its development, therefore, some new theories have been developed to challenge the basis of jus cogens.
\end{abstract}

Copyright (C) 2019 HALREV. All rights reserved.

\section{Introduction}

Theoretically, jus cogens is considered as a problematic term in international law. The scope of jus cogens enumerated in Article 53 of the Vienna Convention on the Law of Treaties (VCLT) 1969, regardless there is no clarity on the definition of jus cogens. The ability of jus cogens to override international treaties and to be "above" state consent with 
the absence of clear definitions, indicates that jus cogens has an important position in international law.

Article 53 VCLT 1969 provides that norms of jus cogens are norms that cannot be override by other norms. However, the Article 53 does not explain why do jus cogens have the highest status compared to other international legal norms. Alexander Orakhelasvili, states that each norm encompasses a substantive content and gain acceptance from states to identify whether the norm achieved the status of jus cogens. ${ }^{1}$ Abi Saab responded by argues that a jus cogens norm is observed from the consequences of the existence of the norm. Special criteria must provide a definition of material aspects that explain why do a jus cogens character that is inherent in a norm have a close relationship that cannot be ruled out. ${ }^{2}$ Furthermore, Orakhelasvili also provides a comparison that there is a term regional jus cogens, which has also been recognized by several international legal experts. The regional jus cogens is condition where a norm is considered to have highest and superior status and the states of the region recognize the norm as the norm of jus cogens. However, the existence of the regional jus cogens principle is certainly contrary to the application of Article 53 VCLT. The article explains that a jus cogens norm is a norm that must be accepted and recognized by the international community at large.

International law does not provide a clear definition of jus cogens. However, international law scholars recognized that jus cogens is a norm with a special characteristics. Multiply analyses are required to categorize a norm as a jus cogens norm. One of the basic requirements to categorize a norm as a jus cogens norm is that if the norm has been adhered to and is recognized in international law. For example, in national legal system, government impose public order as a norm that must be obeyed by the society. This is an evidence and a condition that must be fulfilled since the norm has become a customary law. It is also a condition of a norm to be categorized as a norm of jus cogens. ${ }^{3}$ Wolff, explains that with the intention of states to implement, to obey, and to accept a norm as a legal obligation, the norm is considered as one of the customary laws. The acceptance of a norm that has been recognized by states is a condition where a norm can be classified as a superior norm and must be prioritized. ${ }^{4}$

Vattel also expresses the importance of natural law that binding states without derogation. States are prevented from making any changes by agreement and there is no possibility of renunciation. Vattel says,

It is by the application of this principle that a distinction can be made between lawful and unlawful treaties or convention and between customs which are innocent and reasonable and those which are unjust and deserving of condemnation.

Things, which are just in themselves and permitted by the necessary Law of Nations, may form the subject of an agreement by Nations or may be given sacredness and force through force and custom. Indifferent affairs may be settled either by treaty, if Nations so please, or by the introduction of some suitable custom or usage. But all treaties and custom contrary to the dictates of the necessary law of nations are unlawful. ${ }^{5}$

Furthermore, Vattel also emphasizes the principle of lex specialis, which generally allows state to override or modify general principles of international law. However, this principle cannot be applied if the agreements established between states are contrary to

\footnotetext{
1 Alexander Orakhelasvili. (2006). Peremptory Norms in International Law, Oxford: Oxford University Press p. 43.

2 Ibid.

3 Ibid., p. 36.

4 Wolff. (1993). The Law of Nations Treated according to a Scientific Method, Oxford: Oxford University Press, 1933, p. 10.

5 Alexander Orakhelasvili, Op. Cit., p. 37.
} 
the laws of the nations, which cannot be excluded. It is in line with Vattel's view of the essence of peremptory norms in international relations emphasizes the question of whether natural law is the basis of the existence of peremptory norms. The fundamental argument for this question both at the levels of theory and practice is to uphold international jus cogens norms to prosecute war criminals in Nuremberg. The main norm at issue is not the existence of individual accountability, but the characters of war crimes and their trial without the need for states' approval. 6

\section{Jus Cogens' Theoretical Platform in International Law}

To find out the origin and evolution of jus cogens concept in international law theory, which has been existed in the 17th century until now, it is important to identify three main theories regarding jus cogens: positivist, natural law, and public order theory. There is an inaccurate understanding among international jurists who state that the term peremptory norm is only a result of the findings of the $21^{\text {st }}$ century by not giving any precedent to the theory of international law. Classical international jurists, such as Hugo Grotius, Emer de Vattel, and Christian Wolff illustrate that, in Roman law, there is a difference between jus dispositivum, voluntary law or binding law, based on the agreement of those who wish to bind themselves and jus scriptum (obligatory law) or binding law without the consent of the parties. Differentiation is needed to show agreement (consensus) among states on important principles of international law that directly binds all states without any agreement. ${ }^{\text {This }}$ is of course different from the general obligation that comes from an international agreement or a customary, the norm jus scriptum does not allow derogations. Vattel states that this is because the norm originates from the highest source and natural law.

We use the term necessary Law of Nations for that law which results from applying the natural law to Nations. It is necessary, because Nations are absolutely bound to observe it... This same law is called by Grotius and his followers the internal law of Nations, inasmuch as it is binding upon the conscience of nations... It is by the application of this principle that a distinction can be made between lawful and unlawful treaties or conventions and between customs which are innocent and reasonable and those which are unjust and deserving condemnation. 8

Even after the theory of natural law gained opposition from various parties during the $19^{\text {th }}$ century, one of which was due to the emergence of positive legal theory, the classical concept of peremptory norm remains influential for the theory of international law to modern times. International law experts in the early twentieth century such as Oppenheim and William Hall make it clear that state cannot override some principles of international law that have been recognized universally. In addition, at a practical level, judges at the Permanent Court of International Justice (PCIJ) ensure the existence of peremptory norms in international law by showing an international agreement that is contrary to the contra bonos mores (contrary to public order) in several decisions or dissenting opinions. ${ }^{9}$ Apparently, the PCIJ in this case shows an understanding that

\footnotetext{
6 Belski et.al. (1989). “Implied Waiver under the FSIA: A Proposed Exception to Immunity for Violations of Peremptory Norms of International Law". California Law Review, 77 : 385-387.

7 Evan J. Criddle \& Evan Fox Decent. (2009). "A Fiduciary Theory of Jus Cogens". The Yale Journal of International Law, $34: 334$.

8 Ibid.

9 For example, in the case of Oscar Chinn in 1934, Judge Schucking in his influential dissenting opinion states that both in international courts and arbitration courts, there must not be a provision contrary to bomos mores (or could be interpreted as public order). Oscar Chinn Case, 1934, PCIJ.
} 
there are a number of important or compelling norms (imperatives) that can override agreements made by the parties (states).

Peremptory norm began to attract the attention of of international law scholars since the writing of Alfred von Verdross in 1937 entitled Forbidden Treaties International Law. ${ }^{10}$ Verdross argues that there are several provisions in international customs that have been recognized as having "obligatory" or even compulsory characteristics whilst they are in fact not in accordance with agreements among states. At national level, in which court requires cancellation of contracts if they conflict with the public order, Verdross states that the court must override international agreements that are contrary to international norms of jus cogens (although, in his paper, he does not explain what is meant by the term jus cogens). Verdross defines peremptory law as "ethical minimum recognized by all states of the international community". 11 To illustrate the international jus cogens, Verdross states that a state is burdened with responsibility under international law to carry out some moral tasks, including maintaining public order and legal order, securing inhabitants from external attacks, safeguarding the welfare and security of its citizens and protect citizens who are abroad. Verdross also added that an agreement could be considered violating jus cogens if the agreement calls on the state to close schools or hospitals, to extradite and to sterilize women, to kill children or to take any action that causes citizens to be in danger.

At first, Verdross's view of international jus cogens raised skepticism. His idea against the common view of legal positivism developed by a famous legal experts (such as Hans Kelsen, Georg Schwarzenberger, and International Court Judge Gaetano Morelli). The experts state that a state cannot be bound to an international norm without its consent. They also questioned whether state practice shows a moral consensus that reaches the level of an international jus cogens. ${ }^{12}$ In its development, resistance to jus cogens norms began to fade and, along with the end of World War II, the concept of jus cogens has gained recognition and credibility. The trials of World War II criminals in the Nuremberg and Tokyo courts prove that international law provides substantive limits to the use of state sovereignty as a "shield" of state officials who committed crimes against humanity during World War II to be tried. At the same time, states gathered and agreed on the formation of the Universal Declaration on Human Rights (UDHR) and also establish international treaty, such as the International Convention on Civil and Political Rights (ICCPR) in 1966 which aims to protect human dignity. Furthermore, the judges and international law experts unanimously agree on the existence of an international norm such as a ban on genocide that binds states without their consent. ${ }^{13}$

The emergence of two sources of recognition on human rights norms, namely international conventions and peremptory norms, was concluded in the preparation of the Vienna Convention on the Law of Treaties (VCLT) in the meeting of the International Law Commission in the 1950s and 1960s. At the beginning of the VCLT compilation, supporters of the jus cogens norm received support from an international legal expert, the special rapporteur of International Law Commission (ILC), Sir Hersch Lauterpacht. In March 1953, Lauterpacht included a draft convention on international agreements stating that "an agreement will be null and void if it is not valid under international law

\footnotetext{
${ }^{10}$ Alfred von Verdross. (1937). "Forbidden Treaties in International Law". The American Journal of International Law, 31 (4) : 571-577.

11 Id., p. 574 .

12 Evan J. Criddle \& Evan Fox Decent, Op. Cit., p. 336.

13 See: Advisory Opinion of Internasional Court in Reservation to the Convention on the Prevention and Punishment of the Crime of Genocide, 1951. It states "the principle underlying the Genocide Convention are principles which are recognized by civilized nations as binding on states, even without any conventional obligations".
} 
and if it was declared invalid by the International Court of Justice" ${ }^{14}$ Recognizing the uncertainty regarding the scope and content of jus cogens, Lauterpacht states that peremptory norms originate from two interrelated sources, namely international morality and general legal principles in the practices of states. In the view of Lauterpacht, a norm that overrides the principles of international law, such as the prohibition on slavery, can be categorized as an international public order. These principles can be referred to as a provision of international morality, which is powerful so that international courts regards these principles to represent a principle of international law recognized by the international community, where the International Court of Justice is bound to implement it based on the Statute of the International Court of Justice. By identifying jus cogens as public order and the principles of national law, Lauterpacht ideas is slightly the same with Verdross's that an agreement would fail if it is contrary to international public order.

Although there is widespread acceptance of the existence of jus cogens, still the International Law Commission has not received an agreement on the theoretical basis of peremptory norms or criteria that can be used to identify peremptory norms. Some members of the International Law Commission agree with Lauterpacht that peremptory norms represent minimal rules of international morality ${ }^{15}$ or are norms of public order. Furthermore, most members of the ILC join Sir Humphrey Waldock who was a special rapporteur for the United Nations for international treaties that sought to unite jus cogens with the conventional positivism paradigm. Based on Waldock's formulation, the substance of peremptory norms in international law must be taken from traditional legal sources that reflect state consent, both originating from a custom or an agreement. ${ }^{16}$ Finally, after going through many debates about jus cogens, in 1963, the ILC concluded that "there is not a widely accepted criterion that can define general provisions in international law that have the character of jus cogens" ${ }^{17}$

Article 53 states that "the norm of general international law is a norm accepted and recognized by the international community of states that is permitted and which can be modified only by a subsequent norm of general international law having the same character". This article recognizes jus cogens as an international norm that is non-derogable. However, it does not explicitly state that jus cogens originates from the principle of natural law, state consent, public order, and other theories regarding legal responsibility. Since this article does not identify international norms that are non-derogable, states are "free" to speculate on what can be categorized as the jus cogens norm. Nevertheless, there are clearly-stated examples that a provision is a norm of $j u s$ cogens, such as a commentary of Article 50 of the UN Charter related to the use of armed forces. The Article 50 is stated as "a conspicuous example of a rule in international law having the character of jus cogens". Furthermore, VCLT recognizes the general concept of jus cogens without explicitly codifying the fundamental theories of peremptory norms in international law.

\subsection{Positivism theory}

Most contemporary observers continue to perceive jus cogens through the perspective of positivism that requires state consent. The requirement of state consent is justified on the

\footnotetext{
${ }^{14}$ Hersch Lauterpacht. Law of Treaties: Report by Special Rapporteur : U.N. Doc. A/CN.4/63.

${ }^{15}$ See UN Doc. A/CN.4/156 stating "arguing that jus cogens norm must also be found necessary to international life and deeply rooted in international conscience"

${ }_{16}$ See the Report of the International Law Commission to the General Assembly [1966], UN Doc. A/6309/Rev. 1 “a modification of a rule of jus cogens would today most probably be effected through a general multilateral treaty...)

${ }^{17}$ See Second Report on the Law of Treaties, UN Doc. A/CN.4/156.
} 
basis that a state has the highest sovereignty; therefore, a state cannot be bound by a norm without prior approval. Based on an treaty-based approach, an international norm becomes a mandatory norm (peremptory norms) through the process of forming a law that produces international law. Specifically, states can express agreement with peremptory norms by codifying them in agreements and accepting them as international customary law and applying them as a general principle of law. ${ }^{18}$

Proponents of the positivism theory recognize the "obligatory" nature of international customs that have obtained "mandatory" or compelling status through the practice of state and opinio juris. ${ }^{19}$ Restatement confirms this position by stating that jus cogens "is now widely accepted ... as a principle of customary international law". ${ }^{20}$ For the positivist group, the jus cogens conception that is based on custom supports the legitimacy of international law by ensuring that states maintain good control of their generation and the evolutionary process of peremptory norms. If there is a strain to this group, they will argue by combining jus cogens theory, which is based on custom and state practices. States rarely express their intentions clearly to change an ordinary international customary norm into a peremptory norm. There is also no clear form of state practices (if any), which can support a conclusion of clearly stated intentions. In fact, many criticisms of Jus Cogens, especially that are related to human rights norms, such as the prohibition against torture that has been widely accepted as jus cogens, also in widespread practice, have also been violated. Even if state practices explicitly support peremptory norms that are recognized as international customary law, consent-based approach is difficult to explain why customary norms can bind on persistent objector or cancel an agreement that contradicts it.

If jus cogens cannot be included in the category of international customary law, then the discourse that peremptory norms get their non-derogable status from an international agreement also makes little sense. ${ }^{21}$ The VCLT does not codify norms categorized as jus cogens in the convention, nor does it state that VCLT binds on states that do not ratify it except by consent. Other international conventions such as the International Covenant on Civil and Political Rights (ICCPR) and the Convention on Prevention and Punishment of the Crime of Genocide (Genocide Convention) have incorporated fundamental human rights norms into the convention and urged states to ratify them to provide effective protection for every human being. However, the states' agreement to be bound by these conventions does not mean that a peremptory norm of international law has bound states that are not parties to the convention. The fact that many countries have ratified the Genocide Convention does not mean overriding the need for states that are not parties to the convention to express their consent to be bound by certain provisions of the convention. In fact, the statement that the Genocide Convention produced jus cogens through state consent has been broken by the convention itself, which states that the state party "confirms that genocide ... is a crime under international law" and contains a clause that allows the state to withdraw from the convention. However, it does not mean that the prohibition against genocide is not jus cogens or states

\footnotetext{
${ }_{18}$ Malcolm N. Shaw. (2008). International Law $6^{\text {th }}$ Edition. Cambridge: Cambridge University Press. (which states that only provisions derived from a custom or international agreement can be the basis of a jus cogens norm.)

19 See Michael Byers. (1997). "Conceptualizing the Relationship Between Jus Cogens and Erga Omnes Rules". Nordic Journal of International Law, 66 : 211-212 (arguing that a jus cogens norm is derived from the process of customary international law).

${ }^{20}$ Restatement (Third) of Foreign Relations of The United States 1987.

${ }^{21}$ Evan J. Criddle \& Evan Fox Decent, Op. Cit., p. 340.
} 
that there is no relationship between peremptory norms and international agreements. ${ }^{22}$ What can be ascertained is that, in their practices, multilateral conventions that codify international norms are insufficient to identify these norms as mandatory (peremptory).

\subsection{Natural law theory}

One response to the shortcomings of the positivism theory of jus cogens is that peremptory norms are inherited from the tradition of natural law. Inspired by Lauterpacht who is anti-positivism, some experts argue that peremptory norms get privileged status from moral authority. For example, a member of the International Law Commission Mustafa Kamil Yeseen included in the VCLT formation process that the only possible criterion for distinguishing "ordinary" international customs from norms is to look at the substance of the provisions, including looking at whether these provisions are indeed rooted in international community. ${ }^{23}$ Later, human rights law experts such as Louis Henkin and Louis Sohn have proposed that jus cogens norms such as prohibitions on slavery and military aggression obtain peremptory status from moral and rational authority rather than through states agreement. ${ }^{24}$ As with international treaties, international customs, the general principles of international law can recognize and incorporate the norms of jus cogens but they cannot rule them out. The same recognition that jus cogens as a natural law is stipulated in the jurisprudence of the International Court ${ }^{25}$ and the Inter American Commission on Human Rights. ${ }^{26}$

The conceptual challenges to the theory of natural law have been put forward. Proponents of positivism argue that the concept of natural law regarding jus cogens juxtaposes law and morality, thus confusing the boundaries and relations between ethical norms and objective principles of legal rights and obligations. ${ }^{27}$ It is rather difficult for the natural law theory as the legal positivism theory seeks to explain how peremptory norms can provide substantive limits to actions taken by state without violating the principle of state sovereignty. On this basis, experts are starting to look at other theories that could explain the basis of the binding of jus cogens apart from the concepts of natural law and legal positivism.

\subsection{Public order theory}

The third tradition of international legal theory defines jus cogens as the norm of public order, which is important for the unity of international law as a legal system. Based on this theory, international law recognizes important (imperative) norms, which are hierarchically higher than ordinary norms and customary international law in order to advance the interests of the international community and to preserve the main values of international law so as not to be divided. ${ }^{28}$ Based on the theory of public order, all peremptory norms have two main functions, both functioning to maintain peace

\footnotetext{
22 In the Advisory opinion "Reservation to the Convention on the Prevention and Punishment of the Crime of Genocide" 1951, the court states a contrary that "ICJ has held that principles outlined in the Genocide Convention (as opposed to its specific provision) are "universal" and "binding on states, even without any conventional obligation".

${ }^{23}$ Ibid., p. 342.

24 Ibid., p. 343.

25 Nicaragua case 1986

26 See the case of Domingues v. United States, report No. 62/

27 See A. Mark Weisburd. (1995). "The Emptiness of the Concept of Jus Cogens - as Illustrated by the war in Bosniaherzegovina", Michigan Journal of International Law, 17. Stating that 'natural law "risks falling into the error of assuming that, if it would be a good thing for subject of a legal system to refrain from particular behavior, it must make sense to render the behavior illegal"

${ }^{28}$ Evan J. Criddle \& Evan Fox Decent, Op. Cit., p. 344.
} 
between states as parts of the international community and to reward normative commitments to the main international system. ${ }^{29}$

The theory of public order has stated that the violation of jus cogens is an act against the international community as a whole, this approach places peremptory norms adjacent to the provisions of erga omnes, which allows states that are not affected directly to react. The International Court of Justice explicitly states the concept of obligation erga omnes in the case of Barcelona Traction and emphasizes states to refrain from acts of aggression and genocide and to respect the principles and provisions regarding the fundamental rights of every human being, including protection from slavery and racial discrimination. The Court categorizes these norms as "the obligations of a state to the international community as a whole". 30 The statement from the court attempts to frame peremptory norms as an obligation that must be fulfilled by the international community as a whole, while actually provides difficulties in conceptual matters. In what ways does the international community suffer losses when a country commits slavery or racial discrimination against its own citizens? The next question that arises is why the international community as a whole can sue for a violation that occurs in other states than those who live in the states.

The theory of public order seeks to answer this dilemma by reiterating that peremptory norms are a principle element of normative and constitutive goals of international law from the international community as a whole. ${ }^{31}$ Myers McDougal, Harold Lasswell, and Michael Reisman argue that jus cogens norms such as the prohibition of acts of aggression and racial discrimination show the transformation of international law into a global community that respects human rights and peaceful relations among states. Supporters of this theory show evidence as contained in the Charter of the United Nations, which states the aim of the United Nations is to promote international peace and security, good relations among states, protection of human rights and fundamental freedoms. ${ }^{32}$ Therefore, when the international community accepts the mission of the United Nations, the discourse that peremptory norms is an international policy is quite reasonable.

\section{The Relationship between Jus Cogens and Fundamental Provisions in International Law}

\subsection{Obligation erga omnes}

Discussions often arise within the scope of international law regarding the concept of $j u s$ cogens and obligation erga omnes. Discourse emerged that these two concepts are identical or the same (two side of the same coin), but there are also those who argue that these two concepts are different. In general, the obligation erga omnes does not only cover all or part of the norms of Jus Cogens, but also regulates the status and boundaries of states, cities, islands, and regions that are internationalized, which can be easily modified by an agreement. Particularly with regard to its legal consequences, it is doubtful that all cases related to unilateral violations of $j$ us cogens trigger responsibility for all states, or are only intended for widespread offenses. ${ }^{33}$ For those who argue that these two concepts are different, for example in the context of international criminal law, jus cogens is defined

\footnotetext{
${ }^{29}$ Alexander Orakhelashvili, Op. Cit, p. 131.

30 Barcelona Traction, Light \& Power Co. (Belgium v. Spain), 1970.

31 Evan J. Criddle \& Evan Fox Decent, Op. Cit., p. 345.

32 The UN Charter, Article 1.

33 Stefan Kadelbach. "The Fundamental Rules of International Legal Order-Jus Cogens and Obligation Erga Omnes" on Christian Tomuschat and Jean-Marc Thouvenin (eds.). (2006). Leiden: Martinus Nijhoff, p. 26.
} 
as a certain legal status that has been achieved by an international crime and the obligation erga omnes is defined as legal consequences arising from a particular crime that has been categorized as jus cogens. Therefore, these two concepts are considered as two different concepts. 34

The fundamental rules can be distinguished by looking at the legal consequences produced. Jus cogens specifically states that a provision that conflicts with it will be null and void (Article 53 and 64 of the VCLT 1969) and confirms the prohibition on reservations in terms of the agreement included in jus cogens. On the other hand, the obligation of erga omnes, so far, is considered included in the scope of states' responsibility and interpreted as states' obligation to the international community. The obligation to prevent states from being harmed by other states that violate the provisions of international law submitting claims against these violations is only because a state is a member of the international community and this violation has an effect on the international community as a whole. Meanwhile, the ILC has proposed a distinction between jus cogens and obligation erga omnes (norms that give obligations to states to the international community as a whole), and then propose that these two concepts are two different things. 35

The concept of obligation erga omnes falls within the scope of states' responsibility. Unlike jus cogens, the obligation erga omnes is not explained in the VCLT 1969. This is due to the international provisions regarding states' responsibility have not yet become an international convention that binds states. It is not easy to find criteria that explain what is meant by erga omnes responsibility.

The International Court of Justice has several times referred to the erga omnes norms in deciding cases and described them as the "obligations towards the international community of states as a whole". In the decision of the Barcelona Traction, "the outlawing of acts of aggression, and of genocide, as also [...] principles and rules concerning basic rights of human rights, including protection from slavery and racial discrimination" are mentioned as examples of obligation erga omnes. ${ }^{36}$ The decision of the cases of Namibia and East Timor are added to the list to be categorized as obligation erga omnes, the right to selfdetermination..$^{37}$ In the advisory opinion of the Wall in the Occupied Palestinian Territory, this statement is reaffirmed. This opinion is aimed at certain obligations in international humanitarian law. This is stated by looking at the practice of jurisprudence, which is quite interesting as the legal opinion in the case of Nuclear Weapon.

"a great many rules of humanitarian law applicable in armed conflict are so fundamental to the respect of the human person and 'elementary considerations of humanity' ... that they are to be observed by all States whether or not they have ratified the conventions that contain them, because they constitute intransgressible principles of international customary law ... In the Court's view, these rules incorporate obligations which are essentially of an erga omnes character."

In the legal opinion, this case contained the term "elementary consideration of humanity" inspired by the Martens Clause, which was used for the first time by the Court in the Corfu Channel case. It indirectly refers to the use of the jus cogens norm even

\footnotetext{
${ }^{34}$ M. Cherif Bassiouni, Op. Cit., p. 1.

35 Ibid., p. 28

${ }^{36}$ ICJ Reports 1970, p. 2, para. 33; with respect to genocide see also Application of the Convention on the Prevention and Punishment of the Crime of Genocide, Preliminary Objections, ICJ Reports 1996 (II), p. 616, para. 31; Case Concerning Armed Activities on the Territory of the Congo (New Application) (supra, note 52), at para. 71.

${ }_{37}$ Namibia, ICJ Reports 1971, p. 15, para. 126; East Timor, ICJ Reports 1995, p. 102, para. 29.
} 
though it was not mentioned explicitly. The above quotation implies that Article 1 of the common article 38 of the 1949 Geneva Convention advocates and ensures respect for everyone in any condition. It indicates the erga omnes character of humanitarian law. As mentioned above, the argument is used as an evidence that some provisions in this convention can be categorized as the jus cogens norms. However, the court still insists on the "tradition" not to mention explicitly the term jus cogens. Therefore, this action opens up opportunities for any speculation that is a part of the norms of jus cogens and the norms of erga omnes.

The Special Rapporteur of the International Law Commission (ILC) regarding state responsibility is not involved in considerations related to the main provisions and limits to only following the verdict of the Barcelona Traction case when answering what questions are examples of obligations to the international community. In articles on State Responsibility 2001, ILC did not use the term Erga Omnes, but found other concepts mentioned at a glance, namely: obligation vis-à-vis the international community, peremptory norms (jus cogens) and grave breaches of international law.

\subsection{Customary international law}

Some experts say that the norm jus cogens can be considered a "super customary law". However, experts also distinguish between international customary law and jus cogens. The difference is, among other things, to be stated as international customary law must be fulfilled two main elements, namely the practice carried out widely and consistently among countries and opino juris necessitates, meaning that the practice has been considered a legal obligation and binding states. What needs to be underlined is that an international customary law that has fulfilled these elements binds states including ones that do not follow the beginning of the emergence of customary international law. Then it is observed that customary international law is universal. However, there is an exception, namely persistent objector, meaning that if a state has rejected existence or application of such customary international law consistently and repeatedly, the customary law does not bind the state. Unlike jus cogens, there is no persistent objector or, in other words, jus cogens norms apply to all states whether the state has objections or does not become an object of jus cogens. 39

Customary international law is the second source of international law contained in Article 38 (1) of the Statute of the International Court of Justice. To be more precisely, it mentions "international custom, as evidence of a general practice accepted as law". The international court has strengthened international customs as a source of international law through several decisions. They are, among others, in the Nicaragua Case stating that there are two elements of an international customary law, namely objective elements (general practice) and subjective elements (have been accepted as law). Then, in Asylum Case: Columbia v. Peru (1950) The International Court of Justice describes habits as "constant and uniform usage, accepted as law". Often, there are debates whether or not one condition is enough to be said as customary international law. There must be a level of repetition in a period. This is what the International Court of Justice uses as a reference. ${ }^{40}$ However, it should also be considered that the court states this in the Asylum case context: "The facts ... disclose so much uncertainty and contradiction, so much

\footnotetext{
38 Common article is a term which is used to state articles with a same provisions in the fourth Geneva Convention 1949.

${ }^{39}$ Dan Dubois. (2009). "The Authority of Peremptory Norms in International Law: State Consent or Natural Law?". Nordic Journal of International Law, 78: 137.

40 Peter Malanczuk. (1997). Akehurt's Modern Introduction to International Law $7^{\text {th }}$ revised edition. New York: Routledge. p. 49.
} 
fluctuation and discrepancy in the exercise of diplomatic asylum and official views expressed on various occasions ... that it is not possible to discern ... any constant and uniform usage, accepted as law". In this case, Victor Raul Haya de la Tore, the leader of a failed 1948 uprising in Peru received asylum at the Colombian Embassy in Lima, Peru. Colombia and Peru filed a case with the International Court of Justice questioning whether Colombia has the right to give asylum or Victor Raul must be returned to the Peruvian government or allowed to leave Peru. In other words, this case cannot be categorized as an customary international law. It is not because there is no repetition, but because there is no consistency in practice.

In the Asylum case, the court does not mention the level of uniformity of the practice that occurs and the precise period (duration) so that a condition can be declared to meet the criteria of "constant and uniform". The Court also does not provide an indication of what evidence is needed so that repetitive and uniform actions can be categorized as customary international law. ${ }^{41}$ For example, there is the possibility of repeated practices such as respect for high-ranking officers in an armed force of a friendly state. This practice cannot be regarded as a rule of law and it is precisely categorized as respect. The most important thing is to determine the practice that occurs as an international customary law. In essence, to be categorized as an international customary law, an event should contain a duration of practice, acceptance and consistency of the practice, acceptance of the practice as law or the opini juris sive necessitatis and generality of the practice. 42

\subsubsection{Duration of the practice}

Based on the jurisprudence of the International Court of Justice, it is seen that there is no duration or period needed from an event or condition to be declared as a customary international law. In the North Sea Continental Shelf Cases: FRG v. Denmark \& FRG v. The Netherland (1969), the Court states that there is no duration or a clear period for an event to be declared an international custom. It needs only the practice to be carried out long enough to show that the preconditions of another custom have been fulfilled.

"Although the passage of only a short period of time is not necessarily, or of itself, a bar to the formation of a new rule of customary international law on the basis of what was originally a purely conventional rule, an dispensable requirement would be that within the period in question, short though it might be, state practice, including that of states whose interests are specially affected, should have been both extensive and virtually uniform in the sense of the provision invoked and should moreover have occurred in such a way as to show a general recognition that a rule of law or legal obligation is involved".

\subsubsection{Uniformity and consistency of a practice}

The lack of clear consistency in practice will result in the formation of an customary international law. In the Asylum Case the court states:

"The facts brought to the knowledge of the court disclose so much uncertainty and contradiction, so much fluctuation and discrepancy in the exercise of diplomatic asylum and in the official views expressed on different occasion; there has been so much inconsistency in the rapid succession of conventions on asylum, ratified by some states and rejected by others, and the practice has been so much influenced by consideration of

${ }^{41}$ Alina Kaczorowska. (2002). Public International Law, London: Old Bailey Press. p. 15.

${ }^{42} \mathrm{Ibid}, \mathrm{pp} .16-19$. 
political expediency in the various cases, that is not possible to discern in all this any constant and uniform usage, accepted as law..."

However, uniformity is absolutely not needed and the lack of inconsistency will not result in the formation of customary international law. In the North Sea Continental Shelf Case, the court states that the practice of state must be "extensive and virtually uniform". Statements regarding consistency and uniformity were raised again in the case of Nicaragua, and the court states that there is no need for a state practice to be carried out purely and consistently to create an customary international law. By showing that generally the practice is consistent with the inconsistent provisions and actions is only considered as a minor violation of the prevailing practice, it is still considered that customary international law is valid.

Nevertheless, there is something interesting here: although the International Court of Justice has always stressed the importance of the "constant and uniform usage" factor, in the case of Arrest Warrant (2002) the Court seems to create an "exception". In this case, the Court states that the Minister of Foreign Affairs was immune from the jurisdiction of foreign court crimes on the grounds that the nature, function, and duties of the Minister of Foreign Affairs required to obtain such immunity.43 This opinion is opposed by ad hoc Judge Van den Wyngaert who considers that the Court less than optimal in finding evidence that the practice is a "constant and uniform" practice. 44 This Court decision is inappropriate and, therefore, must be limited only to this case and should not be used as a precedent to ignore material requirements in determining a practice to become a legally binding international practice. ${ }^{45}$

\subsubsection{Opinio juris sive necessitatis}

To be categorized as customary international law, the provision must be considered a binding law. Therefore, states must submit and comply with these provisions. This is what distinguishes customary international law from the norms of state relationship, which are based more on the habits carried out by states without any legal obligation, for example by paying respect to ships flagged by other state's ships sailing on the sea. The main reason for the inclusion of this condition is to distinguish customary international law from habits that do not have the consequences of certain laws (usage).

Furthermore, can opinio juris be assumed to be the general practice of states or does it really have to be explicitly proven? In the case of the North Sea Continental Shelf, the International Court of Justice stated that the opinio juris must be proven.

"Not only must the acts concerned amount to a settled practice, but they must also be such, or be carried out in such a way, as to be evidence of a belief that this practice is rendered obligatory by the existence of a law requiring it. The need of such belief, ie the existence of a subjective element, is implicit in the very notion of a opinio juris sive necessitatis. The states concerned must therefore feel that they are conforming to what amounts to a legal obligation. The frequency or even habitual character of the acts is not in itself enough. There are many international acts, eg in the field of ceremonial and protocol, which are performed almost invariably, but which are motivated only by consideration or courtesy, convience or tradition and not by any sense of legal duty."

\footnotetext{
${ }^{43}$ ICJ Rep. (2002), p. 3

${ }^{44}$ Dissenting Opinion Hakim ad hoc Van den Wyngaert dalam kasus Arrest Warrant . ICJ Rep. (2002), pp. 143-151.

${ }^{45}$ John Dugard. (2013). International Law: A South African Perspective $3^{\text {rd }}$ edition. Kenwyn: Juta \& Company Ltd. p. 33.
} 
However, there were opinions from several judges who disagree with the terms of the opinio juris. Judge Sorenson agreed with Lauterpacht's opinion that because of the difficulty in establishing an opinio juris, uniform implementation could be stated as customary law. On the other hand, Judge Tanaka states the contrary that the opinio juris can be observed from the need for these provisions in international law. In the case of Nicaragua, the majority of judges accept that in a case if there is customary international law together with international treaty law with the same problem, then the opinio juris can be concluded based on the actions of the parties to the agreement. However, this approach raises criticism because it compares two sources of obligation, namely an international agreement that binds because of the agreement of parties; conversely, international custom becomes law when state practice has been accepted as binding. In essence, the court emphasizes a state practice that is not merely considered an ordinary act but which is indeed considered a binding legal provision. 46

Problems that are related to fulfilment of opinio juris are mostly related to evidence: when and how to prove that a state has accepted a habit as legally binding. The burden of proof lies on state, which suggests the existence of a customary practice. Insufficient evidence of opinio juris will result on the failure of determining a practice as customary international law. This was demonstrated, for example, in the case of Lotus (1927) between France and Turkey. In this case, France put forward several examples of actions that their ship crew had refrained from committing criminal acts. However, the Court rejected it, because France failed to prove that it was done consciously as a legal obligation. This is also stated in the case of the North Sea Continental Shelf. Although the principle of equidistance has been implemented in determining the continental shelf boundary for adjacent states, the Court is of the opinion that this is an insufficient evidence. Furthermore, the Court states as follow:

"...that they so acted because they felt legally compelled to draw them in this way by reason of rule of customary law obliging them to do so-especially considering that they might have been motivated by other factors". 47

The relation between the opinio juris and opinio necessitates in fulfilling psychological requirements of a practice to become customary international law needs further elaboration. Do the two elements have fulfilled altogether, or not? Opinio necessitatis means non-legal factors such as economy, social, and politics, which lead to a custom. An international custom emerged because of the demands of these factors. If the custom does not have objections or opposition from other states, it is even widely accepted and consciously accepted as a legal obligation. Then, the custom by itself has become opinio juris. In this stage, the attachment of states to these custom is no longer solely based on economic, social, and political considerations (opinio necessitatis), but has considered it a legal obligation (opino juris). 48 The correct example to be put forward includes the arrangement of the continental shelf. The regulation was initially encouraged, among others, by economic considerations attached to the continental shelf (opinio necessitatis), but then the states accepted it as a legal obligation (opinio juris).

\subsubsection{General State Practices}

Recognition of certain provisions as international law by most countries produces an assumption that these provisions have been generally accepted. These provisions bind

\footnotetext{
${ }^{46} \mathrm{Ibid}, \mathrm{p} .18$.

${ }^{47}$ ICJ Rep (1969), pp. 44-45.

${ }^{48}$ See Cassese, pp. 157-158
} 
states in general and states can only reject the application of these provisions if it has expressed objections continuously to their application since it was first established (persistent objector).

General application is not required to create a customary international law and the application of these provisions by a small number of states and the absence of practices that contradict these provisions adequately indicate the existence of a customary international law. Therefore, customary international law can be applied even if only for a number of states. As stated in the Asylum Case decision.

"The Columbian government has finally invoked 'American international law in general' ... it has relied on an alleged regional or local custom particular to Latin American States. The Party which relies on a custom of this kind must prove that this custom is established in such a manner that it has become binding on the other party. The Columbian government must prove that the rule invoked by it is in accordance with a constant and uniform usage practiced by the states in question, and that this usage is the expression of a right appertaining to the state granting asylum and a duty incumbent on the territorial state. This follows from article 38 of the statute of the court, which refers to international custom "as evidence of a general practice accepted as law".

With regard to the correlation between jus cogens, the concept of obligation erga omnes, and customary international law, several things should be underlined. As previously stated, jus cogens is a "compelling law" which is the highest legal source in international law. The term jus cogens is actually not included in Article 38 (1) of The Statute of the International Court, which is considered as a source of formal and material law. Although the article is not explicitly stated as a source of law, the court judges uses this article as a guideline in deciding cases. The term jus cogens or peremptory norm (both of these terms are often used interchangeably) can only be found in Article 53 of VCLT 1969. Similar point happens to the term erga omnes, there is no clear definition of what is meant by this term. This concept mentioned for the first time in the case of Barcelona Traction in the International Court of Justice by stating that the legal obligation is intended as an obligation to the international community as a whole. However, the court does not elaborate on the legal regime of obligation. This concept has been developed from cases decided by the International Court of Justice but the content and the effects are still unclear.

Although there is no clear definition of the two terms, there is a connection between jus cogens and the legal obligation in cases decided by the court. In the case of Barcelona Traction, the words used are "the international community as a whole". It actually refers to Article 53 VCLT. Furthermore, the example given in the Barcelona Traction case is also an example used by the International Law Commission in the VCLT discussion. In the separate opinion, Judge Ammoun also mentioned about jus cogens and related it to the obligation erga omnes. ${ }^{49}$ It affirmed that the court has justified the jus cogens concept when introducing the concept of obligation erga omnes. Further, the court strengthened it in the case of East Timor (1995) and the Advisory Opinion on the Legal Consequences of the Wall in the Occupied Palestinian Territories (2004). Even in the East Timor case, the court states that the obligation to protect the right to self-determination was an obligation erga omnes. However, the court refused the case for the reason that court has no jurisdiction. ${ }^{50}$

\footnotetext{
49 Separate opinion of Judge Ammoun, Case Concerning the Barcelona Traction, Light and Power Company Ltd (Belgium v. Spain), 5 February 1970, ICJ Rep. 1970.

${ }^{50}$ Case concerning East Timor (Portugal v. Australia), 30 June 1995, ICJ Rep. 1995.
} 
In the case of the Wall of Palestine, the court stated that Israel had violated the right to self-determination of the Palestinian people as well as several obligations under international humanitarian law and this is included in the obligation erga omnes. 51 Furthermore, to determine the obligations of other states if there is a violation of the obligations erga omnes, the Court implicitly applies Article 41 of the 2001 Articles on State Responsibility, which obliges states not to recognize any conditions that originate from violations of a peremptory norm, or provide assistance that can sustain the situation. ${ }^{52}$

The relationship between jus cogens and obligation erga omnes is also recognized in cases decided beyond the International Court of Justice. In Furundzija's case ${ }^{53}$, the ICTY states that the prohibition on torture was included in the obligation erga omnes and was a mandatory norm in the general principles of international law. The Kupreskic case states that the norms of international humanitarian law (including the prohibition against genocide) are the norm of jus cogens and the obligation erga omnes. ${ }^{54}$ Observing these two terms, it can be inferred that jus cogens deals with hierarchies of international norms and interests, while erga omnes obligations are related to enforcement with peremptory norms. In particular, violations of the jus cogens norm, which are very basic for the international community can provide legal interests for each country to be able to submit to these norms. As a result, if there is a violation of the norm, each country in the world, even if it does not directly affected by the violation, has an interest in protecting this norm and can take steps to enforce it.

Furthermore, to discuss the relationship between jus cogens and customary international law, we can view several similarities. The Article 53 of VCLT reads

"A treaty is void, if, at the time of its conclusion, it conflicts with a peremptory norm of general international law. For the purpose of the present convention, a peremptory norm of general international law is a norm accepted and recognized by the international community of states as a whole, as a norm from which no derogation is permitted and which can be modified only by a subsequent norm of general international law having the same character".

It is stated that the jus cogens norm is a norm that is accepted and recognized by the international community as a whole, while the customary international law must fulfil the material and subjective elements. The material element requires that the practice be carried out broadly and uniformly by states (extensive and virtually uniform), like in the case of the North Sea Continental Shelf (1969). The International Court of Justice states "...State practice, including that of State whose interests are specially affected, should...be both extensive and virtually uniform". 55

Furthermore, the constant and uniform usage must be fulfilled as confirmed by the International Court of Justice in the case of Asylum (1950) that a state practice can be recognized as law. What needs to be underlined is the consistent element, given that the frequency element is not enough because what is more important is consistency in carrying out the habit. Material required by Article 38 (1) of The Statute of the International Court of Justice is a general practice or practice in general, not a practice

\footnotetext{
51 Advisory Opinion on the Legal Consequences of the Construction of a Wall in the Occupied Palestinian Territories, para. 155-157.

52 Advisory Opinion on the Legal Consequences of the Construction of a Wall in the Occupied Palestinian Territories, para. 159.

53 Prosecutor v. Anto Furundzija, Case No. IT-95-17/1-T, Trial Chamber II, 10 December 1998, para. 144 and para. 151154

54 Prosecutor v. Zoran Kupreškic et al., Case No. IT-95-16, Trial Chamber II, 14 January 2000, para. 519-520

55 ICJ Rep. (1969), p. 74.
} 
that is universal or widespread. According to Brownlie, this general practice is a complementary factor to the element of consistency, especially when there are protests from some states regarding a practice that turns out differently.

A psychological element that must be fulfilled is a habit, an opinio juris. States must recognize and accept that they are bound to carry out legal obligations arising from the custom (the opinio juris), or according to the sentence in Article 38, these habits (general practice) must be accepted as law.

Some experts say that the norm jus cogens can be considered a "super customary law". However, experts also distinguish customary international law and jus cogens. The difference is, among other things, a customary international law must fulfilled two main elements, namely the practice carried out widely and consistently among states and opinio juris necessitatis meaning that the practice has been considered a legal obligation and binding on states. What needs to be underlined is that a customary international law that has fulfilled these elements binds states, including those that do not follow the beginning of the emergence of international customary law. However, there is an exception, namely persistent objector, meaning that if a state has consistently and repeatedly rejected the existence or application of such customary international law, the customary law does not bind the state. Unlike jus cogens, there is no known persistent objector or, in other words, jus cogens norms apply to all states whether some states have objections or does not become an object of jus cogens. ${ }^{56}$

Broadly speaking, it can be concluded that jus cogens norm is not the norm jus dispositivum, which can be ruled out by unilateral state actions, but it is a norm that has occupied the highest position in international law and has no exceptions in any form.

\section{Conclusion}

There are at least three theories in international law that can answer the theoretical foundation of jus cogens or peremptory norms. They are positivist, natural law, and public order theories. Positivist theory views jus cogens through the point of view of positivism, which states that a law requires state approval. The requirements of states' agreement are justified on the basis that a state has the highest sovereignty. Therefore, a state cannot be bound by a norm without its prior approval. Specifically, states can express agreement with peremptory norms by codifying them in agreements and accepting them as customary international law and applying them as a general legal principle. The theory of natural law states that peremptory norm is inherited from the tradition of natural law. Some experts argue that peremptory norms get privileged status from moral authority. The last, public order theory, defines jus cogens as the norm of public order, which is important for the unity of international law as a legal system. Based on this theory, international law recognizes important (imperative) norms, which are hierarchically higher than ordinary norms and customary international law in order to advance the interests of the international community and preserve the main values of international law. Based on the public order theory, all peremptory norms have two main functions, both functioning to maintain peace between states, as parts of the international community, and to reward normative commitments to the main international system.

${ }^{56}$ Dan Dubois. (2009). “The Authority of Peremptory Norms in International Law: State Consent or Natural Law?". Nordic Journal of International Law, $78: 137$. 
The correlation of jus cogens, obligation erga omnes, and customary international law is that jus cogens relates to hierarchies of norms and international interests; while the obligation erga omnes is related to enforcement of peremptory norms. In particular, violations of jus cogens norm, which are very basic for the international community, can provide legal interests for each state to be able to submit to these norms. As a result, if there is a violation of the norm, each state in the world, even if it does not get a direct result of the violation, has an interest in protecting this norm and can undertake steps to enforce it. In addition, it is necessary for international law to establish clear criteria of $j u s$ cogens immediately, since the elements contained in Article 53 of the VCLT is insufficient to answer the criteria for an international norm to be considered as jus cogens or peremptory norms. In addition, clarification is needed for which institution in international law that hold the authority to determine the criteria for a norm of international law to be accepted as a peremptory norm.

\section{References}

Books:

Alexander Orakhelasvili. (2006). Peremptory Norms in International Law. Oxford: Oxford University Press.

Alina Kaczorowska. (2002). Public International Law, London: Old Bailey Press.

Christian Tomuschat and Jean-Marc Thouvenin (eds.). (2006). The Fundamental Rules of International Legal Order-Jus Cogens and Obligation Erga Omnes". Leiden: Martinus Nijhoff.

John O'Brien. (2001). International Law, United Kingdom: Cavendish Publishing Limited.

Malcolm N. Shaw. (2008). International Law $6^{\text {th }}$ Edition. Cambridge: Cambridge University Press.

Oppenheim, et.al., Oppenheim's International Law Vol. 1 Peace, Introduction \& part I (1992).

Peter Malanczuk. (1997). Akehurt's Modern Introduction to International Law $7^{\text {th }}$ revised edition, New York: Routledge.

Wolff. (1933). The Law of Nations Treated according to a Scientific Method. Oxford: Oxford University Press.

Journals:

A. Mark Weisburd. (1995). “The Emptiness of the Concept of Jus Cogens - as Illustrated by The War in Bosnia-herzegovina". Michigan Journal of International Law, 17.

Alfred von Verdross. (1937). "Forbidden Treaties in International Law". The American Journal of International Law, 31 (4).

Andrea Bianchi. (2008). "Human Rights and the Magic of Jus Cogens", The European Journal of International Law, 19 (3).

Belski et.al. (1989). “Implied Waiver under the FSIA: A Proposed Exception to Immunity for Violations of Peremptory Norms of International Law". California Law Review, 77.

Dan Dubois. (2009). “The Authority of Peremptory Norms in International Law: State Consent or Natural Law?". Nordic Journal of International Law, 78.

Evan J. Criddle \& Evan Fox Decent. (2009). "A Fiduciary Theory of Jus Cogens". The Yale Journal of International Law, 34. 
M. Cherif Bassiouni. (1996). "International Crimes: Jus Cogens and Obligation Erga Omnes", Law and Contemporary Problems, 59 (4).

Michael Byers. (1997). "Conceptualizing the Relationship Between Jus Cogens and Erga Omnes Rules". Nordic Journal of International Law, 66.

Rafael Nieto-Navia. (2001). International Peremptory Norms (Jus Cogens) and International Humanitarian Law. Available from: www.iccnow.org/documents/ WritingColombiaEng.pdf.

Simma. (1995). "The Contribution of Alfred Verdross to the Theory of International Law", European Journal of International Law, 6.

UN Documents:

Hersch Lauterpacht, Law of Treaties: Report by Special Rapporteur, U.N. Doc. A/CN.4/63.

UN Doc. A/CN.4/Report of the International Law Commission to the General Assembly [1966], UN Doc. A/6309/Rev. 1

Second Report on the Law of Treaties, UN Doc. A/CN.4/156.

Cases:

Advisory Opinion on the Legal Consequences of the Construction of a Wall in the Occupied Palestinian Territories.

Barcelona Traction, Light \& Power Co. (Belgium v. Spain), 1970.

Case concerning East Timor (Portugal v. Australia), 30 June 1995, ICJ Rep. 1995.

Military and Paramilitary Activities in and against Nicaragua (Nicaragua v. US), 1986, ICJ.

Prosecutor v. Anto Furundzija, Case No. IT-95-17/1-T, Trial Chamber II, 10 December 1998.

Prosecutor v. Zoran Kupreškic et al., Case No. IT-95-16, Trial Chamber II, 14 January 2000.

Restatement (Third) of Foreign Relations of The United States 1987.

South Africa Case (Ethiopia v. South Africa; Liberia v. South Africa), second phase, Judgement 1966, ICJ Report 298.

\section{Conflict of Interest Statement:}

The author(s) declares that the research was conducted in the absence of any commercial or financial relationships that could be construed as a potential conflict of interest.

Copyright (C) 2019 HALREV. All rights reserved. 